\title{
Drought results in recruitment failure of Rio Grande silvery minnow (Hybognathus amarus), an imperiled, pelagic broadcast-spawning minnow
}

\author{
Thomas P. Archdeacon • Tracy A. Diver-Franssen • \\ Nick G. Bertrand • Joshua D. Grant
}

Received: 18 March 2020 /Revised: 8 June 2020 / Accepted: 5 July 2020 / Published online: 11 July 2020

(C) The Author(s) 2020

\begin{abstract}
As precipitation and temperature patterns change, the resulting alterations in hydrologic conditions may adversely affect some stream fishes. The unique guild of freshwater, pelagic broadcastspawning minnows found in the western United States appears to be particularly sensitive to low-flow conditions. We examined reproductive and recruitment patterns of one of these species, Rio Grande silvery minnow (Hybognathus amarus), over a three-year period, which included one year of extreme drought. We
\end{abstract}

T. P. Archdeacon $(\bowtie) \cdot$ J. D. Grant

New Mexico Fish \& Wildlife Conservation Office, U.S. Fish \& Wildlife Service, 3800 Commons Avenue NENew Mexico 87109 Albuquerque, USA

e-mail: thomas_archdeacon@fws.gov

T. A. Diver-Franssen · N. G. Bertrand

Southwestern Native Resources \& Recovery Center, U.S. Fish \& Wildlife Service, New Mexico 88230 Dexter, USA

Present Address:

T. A. Diver-Franssen

New Mexico Department of Game \& Fish, 7816 Alamo Road

NW, Albuquerque, NM 87120, USA

Present Address:

N. G. Bertrand

U.S. Bureau of Reclamation, Bay-Delta Office, 801 I Street, Suite 140, Sacramento, CA 95814, USA

Present Address:

J. D. Grant

Arizona Cooperative Fish \& Wildlife Research Unit, School of

Natural Resources \& Environment, University of Arizona, ENR2

Room N2-2H, 1064 East Lowell Street, Tucson, AZ 85721, USA followed gonadal development from March through September each year, from 2017 to 2019 , to determine if Rio Grande silvery minnow were reproductively active during extreme drought. The population structure was also monitored to confirm successful recruitment over the same period. We found that in all years Rio Grande silvery minnow were reproductively active in April through early June, including during extreme drought in 2018. However, almost no recruitment occurred in 2018, and by early 2019 the population was dominated by older, wild age- 2 fish and hatchery-reared fishes. Our work supports previous research on pelagic broadcast-spawning minnows and confirms that extreme low-flows results in near-complete recruitment failure of Rio Grande silvery minnow. This work will help inform management and conservation of Rio Grande silvery minnow and other pelagic broadcastspawning minnows during drought or low flows years.

Keywords Pelagic broadcast-spawning · GSI ·

Reproduction $\cdot$ Flow-recruitment $\cdot$ Regulated river $\cdot$ Vital rates

\section{Introduction}

Streamflow patterns are changing globally, and the direction of change is often consistent within a region (Gundmundsson et al. 2019). In many areas of the western United States, changing patterns of precipitation and timing of snowmelt runoff have resulted in less winter precipitation and earlier spring runoff (Stewart 
et al. 2004; Yan et al. 2019; Overpeck and Udall 2020). Declines in supply of winter precipitation have increased the frequency of multi-year droughts in the western United States (Seager et al. 2007), especially when combined with high demands for human water consumption (Blythe and Schmidt 2018). As demand exceeds supply, more aquatic ecosystems may become imperiled without a change in water use and conservation strategies (Glieck 2003). Even once-perennial rivers now experience episodic channel drying due to increased infrastructure intended to supply human demand (Glieck 2003), and many traditionally intermittent streams have contracted flow seasonality.

Many of the aquatic species inhabiting these ecosystems may be poorly adapted to streamflow regimes that differ from those in which they evolved. Conservationists must understand how changes affect lotic systems and devise strategies to help mitigate the effects of these changes. For example, changes to streamflow regimes can favor non-native species, sometimes to the detriment of native species (Seegrist and Gard 1972; Bernardo et al. 2003; Gido and Propst 2012). Reduced streamflow and increased intermittency, among other factors, can restructure aquatic communities and decrease the persistence of native fishes (Ruhí et al. 2015; Ruhí et al. 2016; Kominoski et al. 2018). However, variation in streamflow within a basin may favor some native fishes over others, and the effects appear to be specific to reproductive strategies (Mims and Olden 2012; McManamay and Frimpong 2015, Perkin et al. 2019).

Minnows in the pelagic broadcast-spawning guild (Balon 1975, 1981; Platania and Altenbach 1998) of the Great Plains of western North America may experience recruitment failure during low flows (Durham and Wilde 2006, 2009; Perkin et al. 2019). Minnows in this reproductive guild release non-adhesive, neutrally buoyant eggs directly in the water column (Platania and Altenbach 1998). Longitudinal and latitudinal channel connectivity, which provide access to low-velocity habitats and ability to disperse to other areas, are important for successful recruitment among these species (Pease et al. 2006; Dudley and Platania 2007; Hoagstrom and Turner 2015; Perkin et al. 2015). Given the increase in frequency and severity of drought in the western United States, further investigation of how hydrologic variability drives recruitment success, while pinpointing where failure occurs, is needed to help conserve these native fishes.
The only persisting wild population of Rio Grande silvery minnow (Hybognathus amarus, hereafter RGS minnow) occurs in $\sim 300 \mathrm{~km}$ of the Rio Grande in New Mexico (Bestgen and Platania 1991; Edwards 2017). Rio Grande silvery minnow is a small-bodied minnow with a lifespan of about 3 years, though the majority do not live past 18 months (Horwitz et al. 2018). A member of the pelagic broadcast spawning guild (Platania and Altenbach 1998), RGS minnow has been extirpated from $\sim 90 \%$ of its historical range (Treviño-Robinson 1959; Bestgen and Platania 1991). Channelization and the lack of lateral connectivity have resulted in increased water velocities and poor retention of eggs and larvae in natal areas; many are presumably lost downstream during spawning flows (Dudley and Platania 2007; Widmer et al. 2010). These negative effects on recruitment are further exacerbated by agricultural diversion dams, which act as barriers to upstream movement (Dudley and Platania 2007) and drying $>80 \mathrm{~km}$ of the main channel during summer months (Archdeacon 2016). Several management actions occur annually in an effort to understand and offset negative impacts. These include long-term fish assemblage monitoring (Dudley et al. 2020), rescue of stranded RGS minnow during channel drying (Archdeacon 2016), and augmentation with hatchery-reared fish when natural recruitment is low (Osborne et al. 2012, 2013).

Recent research suggests managed spring runoff and restoration of the channel to create low-velocity nursery habitat can increase retention and recruitment of RGS minnow eggs and larvae (Pease et al. 2006; Dudley and Platania 2007; Valdez et al. 2019). While spawning occurs during the spring suring snowmelt runoff (Valdez et al. 2019), Hutson et al. (2018) speculate it may also occur throughout the summer during monsoon-driven flow spikes. Under current channel conditions, years with higher snowmelt-driven runoff create more of these low-velocity nursery habitats because of increased lateral connectivity to the floodplain (Dudley and Platania 2007). This typically results in more juveniles observed during fish rescue and autumn surveys (Archdeacon 2016; Dudley et al. 2020). Here, we examine trends in reproduction and recruitment of RGS minnow over a three-year period that includes two years of high streamflow and one year of extreme low flow. We build on previous work on the reproduction and flow-recruitment relationships of freshwater pelagic broadcast-spawning species during extreme drought (Durham and Wilde 2006, 2009; Perkin et al. 2019) by 
pairing population monitoring data with reproductive investment data collected during years with differing flow conditions.

Our objectives were to provide insight on reproductive investment and flow-recruitment dynamics of RGS minnow, furthering our knowledge of pelagic broadcast-spawning minnows. To do this, we assessed gonadal development of RGS minnow from February through September for three consecutive years, 2017 to 2019, and compared those data to recruitment data collected over the same period of time. Both 2017 and 2019 had above average precipitation and snowpack leading to above average spring runoff; 2018 in contrast was the lowest spring runoff year in the New Mexico reach of the Rio Grande in the 21st century, resulting in substantial drying (Fig. 1). Based on previous research on pelagic broadcast-spawning minnow that examined reproductive investment and recruitment dynamics (Perkin et al. 2019), we hypothesized that RGS minnow would allocate resources to gonadal development even during the low runoff year in 2018, but would have significantly lower recruitment in this drought year compared to high-flow years.

\section{Materials and methods}

Study area

We studied gonadal development and recruitment of RGS minnow in the San Acacia reach of the Rio Grande of New Mexico. The San Acacia reach extends approximately $145 \mathrm{~km}$ from the San Acacia Diversion Dam to Elephant Butte Dam (Fig. 1). Here, the Rio Grande is almost exclusively a sand-bottomed, braided channel river (Massong et al. 2006; Swanson et al. 2011). The San Acacia Reach is the lowest reach of the Rio Grande inhabited by RGS minnow. We examined daily streamflow at the U.S. Geological Survey gauge below San Acacia Diversion Dam (Fig. 1; gage 08354900) from 2017 to 2019 and compared it to the historical median streamflow from 1974 to 2019 to assess drought severity within this reach. We also examined the monthly Palmer Drought Severity Index for the upper Rio Grande basin in Colorado, which is the major source of snowmelt runoff for the Rio Grande in New Mexico. The contemporary annual flow regime of this reach is driven by snowmelt runoff in spring months, followed by low-flows and intermittency due to a combination of seasonal drought and water abstraction for agriculture, which is often punctuated by North American Monsoon rain events in late summer through early fall (Sheppard et al. 2002), providing brief periods of increased streamflow which may stimulate spawning. Finally, base flows resume at the conclusion of the irrigation season in November.

Gonadal development of Rio Grande silvery minnow

We collected RGS minnow from multiple locations in the San Acacia Reach. In 2017 and 2018 we sampled approximately bi-weekly from February 15 (2018) or March 1 (2017) until approximately September 15. To capture greater resolution during the spawning period in 2019, we sampled once monthly from February 15 through April 15, weekly from April 15 through June 6, and monthly from June 26 until September 15 . We attempted to capture 30 individuals per sampling event and we increased the number of sites as required. However, adult RGS minnow became rare over time within each year, thus it was not always feasible to collect set numbers; later sampling events generally ended with smaller sample sizes.

We collected adult RGS minnow with a seine, backpack electrofishing, or fyke nets depending on streamflow and site access. Our use of multiple gears was necessary to ensure we captured enough fish for analysis. While this may have introduced variability due to differing capture efficiencies among gears, we believe it is unlikely a one gear or another was selective with respect to reproductive investment. Nevertheless, different sampling gear may have targeted different size classes of RGS minnow, which may in turn have influenced reproductive development. Therefore, we conducted a preliminary examination and found standard length did not predict gonadosomatic index (GSI; $F_{1,818}=0.281$, $P=0.60$ ). Thus, while each gear may have been selected for different size classes, there was no relationship between size and GSI, and we attributed changes in GSI to changes in reproductive investment and not bias introduced by gear.

Rio Grande silvery minnow were euthanized in $200 \mathrm{mg} \mathrm{L}^{-1}$ overdose of tricaine methanesulfonate (MS-222, Sigma-Aldrich ${ }^{\mathrm{TM}}$ ) and preserved in $10 \%$ zinc-buffered formalin in the field. A small incision was made in the abdomen after returning fish to the laboratory to allow formalin to penetrate the body 


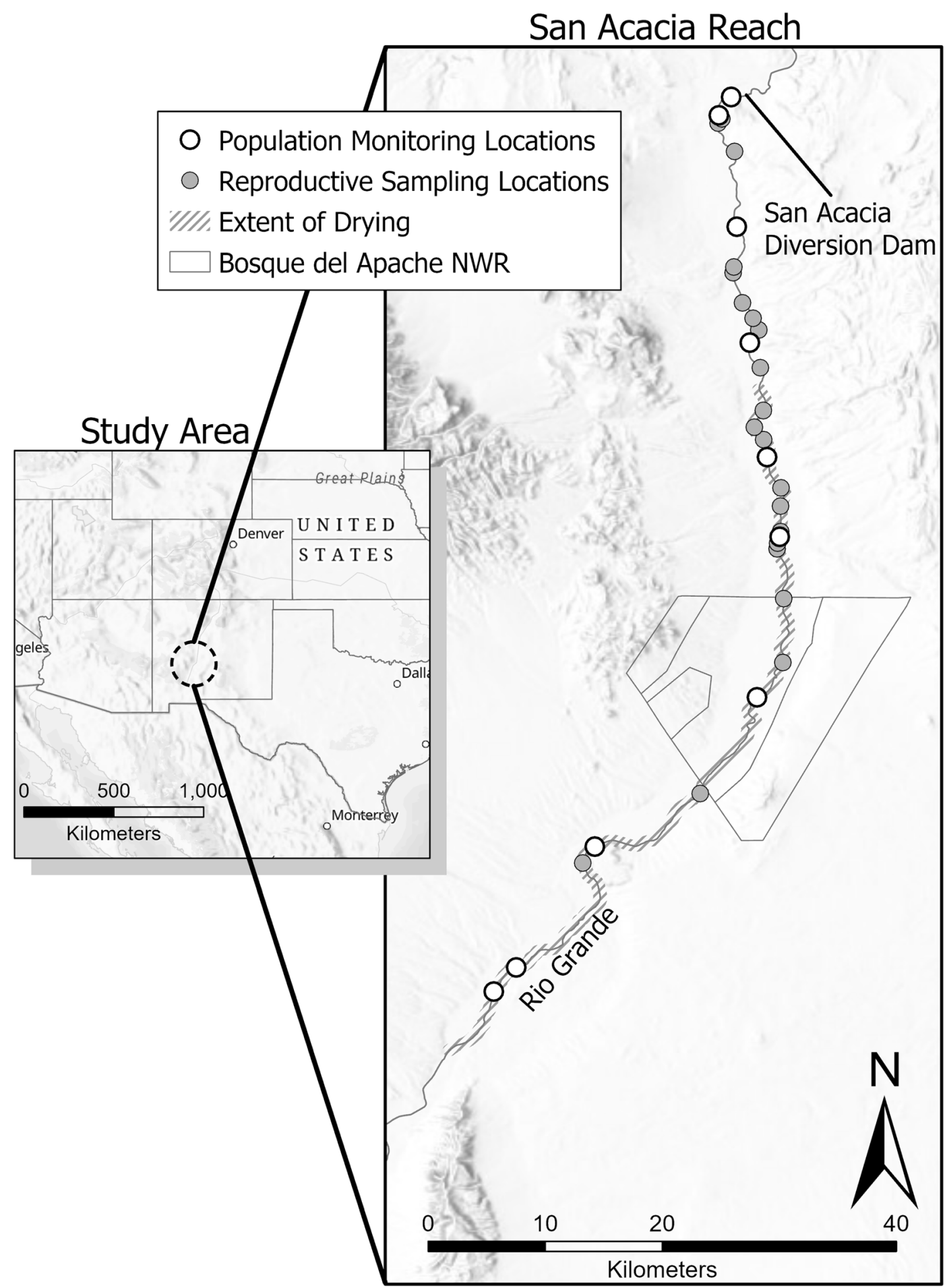

Fig. 1 Map of sampling locations for Rio Grande silvery minnow in the San Acacia reach of the Middle Rio Grande, New Mexico, April to September, 2017-2019. Cross-hatched areas represent channel drying in 2018

cavity. After fixation, fish were placed in water and diluted ethanol washes for 5-7 days and stored in $70 \%$ ethanol until dissection. Only females were used to assess gonadal development. In the laboratory, we 
recorded body mass $( \pm 0.01 \mathrm{~g})$ and measured standard length $( \pm 0.1 \mathrm{~mm})$. We removed ovaries, blotted each side on a paper towel, and allowed residual ethanol to evaporate for $30 \mathrm{~s}$ before recording mass $( \pm 0.0001 \mathrm{~g})$. We calculated gonadosomatic index (Wootton 1998) as

$G S I=\frac{\text { Gonadmass }}{\text { Totalmass }} \times 100$

Gondasomatic index is a commonly used tool to assess reproductive condition in fishes. Gonadosomatic index can be used to determine general spawning condition in many small-bodied cyprinids but may fail to distinguish among more specific reproductive stages (Brewer et al. 2008).

Recruitment of Rio Grande silvery minnow

Fish collections were made as part of a standardized monitoring program for RGS minnow collected from 20 to 30 sites, February through November each year, in New Mexico (Dudley et al. 2020). Fish assemblage data were collected monthly at 10 fixed sites in April and October and nine fixed sites in May through September of each year. To collect fishes, two people drew the seine downstream through a single mesohabitat of uniform depth and velocity. The length of each seine haul $( \pm 0.1 \mathrm{~m})$ was multiplied by the width sampled by the seine (typically $2.5 \mathrm{~m}$ ) to obtain area seined for each haul, each of which was summed to obtain the area seined for each site. Eighteen to twenty hauls were performed in discrete mesohabitats within a $200 \mathrm{~m}$ section of river, which is sufficient effort to reduce sampling error (Archdeacon et al. 2020). Standard length (SL; $\pm 1 \mathrm{~mm}$ ) was measured on all RGS minnow to determine age class. Age-0, Age-1 and Age-2 RGS minnow are generally distinguishable based on standard length (Horwitz et al. 2018). Age-3 fish are rarely collected and not distinguishable from Age-2 fish based on length (Horwitz et al. 2018). Thus, fish were assigned to three age classes, Age-0, Age-1, and Age-2+. Additionally, any fish with a visible implant elastomer tag, indicating release from a hatchery, were recorded separately.

\section{Statistical analyses}

We used generalized additive mixed models to estimate median GSI values for each sampling date (Wood 2011). We fit each year separately, with ordinal day of the year as a smoothing term and site as a random effect using the "gamm" function from package "mgcv" (Wood 2011) in program R (R Core Team 2018). We used a model that assumed a quasipoisson error distribution as GSI is constrained to positive values. We calculated the deviance explained (DE) for each year from the deviance from the null model (intercept only, $\mathrm{DN}$ ) and deviance from the full model (DR) as

$$
D E=\frac{(D N-D R)}{D N} \times 100
$$

\section{Results}

Streamflow

Streamflow was variable within and among years (Fig. 2). Although drying occurred in all three years, it was of short duration, occurred late in the season, and covered only a few kilometers in 2017 and 2019. Conversely, in 2018 drying began in April and extended into October, resulting in $>60 \mathrm{~km}$ of dry channel. Both 2017 and 2019 spring snowmelt runoff were above observed historical averages, while 2018 was well below historical averages (Fig. 2). Palmer Drought Severity Index was near normal $(-2$ to +2$)$ from January through November 2017, shifting to moderate drought $(>-3)$ in December 2017 and January 2018, to severe ( $>-4)$ in February and March 2018, then to extreme $(<-4)$ from April through February of 2019. The Palmer Drought Severity Index fluctuated between moderate drought to near normal for the remainder of 2019.

Gonadal development of Rio Grande silvery minnow

We collected and dissected 820 female RGS minnow from the San Acacia Reach during the study. In all years, GSI varied through the time and was elevated from April through early June (Fig. 2). In 2017, RGS minnow GSI peaked at $11 \%$ in mid-April $(F=53.5, P<0.0001$, deviance explained $=75.5 \%$ ). Similarly, in 2019, GSI peaked in late April at $17 \%(F=12.8, P<0.0001$, deviance explained $=47.5 \%$ ). However, in 2018 peak GSI was $21 \%$ and occurred much later, in mid-May $(F=23.7$, $P<0.0001$, deviance explained $=57.5 \%$ ). At least a few RGS minnow were likely capable of spawning in July and August of 2018 (Fig. 2). However, 150 RGS minnow 
were collected between July 1 and 30 September in all three years. Of these, only two fish had a GSI above $30 \%$ and one additional above $10 \%$ (Fig. 2).

\section{Rio Grande silvery minnow population structure}

Monthly sampling revealed strong recruitment in 2017 , a near lack of recruitment in 2018 , and strong recruitment again in 2019 (Fig. 3). Catch-per-unit-effort of the 2017 cohort steadily declined through time until August 2018. While RGS minnow were present in all collections, catch-per-unit-effort was substantially lower in late 2018 and 2019 following recruitment failure in 2018, and remained low until after spawning occurred in 2019. Recruits appeared in June in both 2017 and 2019, but not until August in 2018 (Fig. 3). Age-0 fish were abundant in $2017(\mathrm{n}=7,931)$ and $2019(\mathrm{n}=$ 1,488 ), but only four age- 0 fish were collected in 2018. A substantial proportion of the spawning biomass in 2019 consisted of Age-2 + and hatchery RGS minnow (Fig. 3).

\section{Discussion}

Our results documented recruitment failure of RGS minnow during extreme drought conditions. Gonadosomatic index revealed that RGS minnow were reproductively active during the extreme drought, as GSI peaked in spring and declined through June and July in all three years. Histological examination of ovaries will be required to determine if follicular atresia occurred in response to drought; however, eggs were collected in the river in 2018 (Dudley et al. 2019), indicating that some degree of spawning occurred. However, stress induced reabsorption mechanisms remain difficult to determine, even with histological methods because reabsorption is often species and context specific. For example, reabsorption is often influenced by environmental stressors, spawning opportunity, and seasonal nutrition (Rideout et al. 2005; Rideout and Tomkiewicz 2011). Nonetheless, very few age-0 recruits were collected during the extreme drought year. Following this failed recruitment, catch-per-unit-effort decreased through the autumn and winter of 2018. Eventually, the RGSM minnow population was dominated by older and hatchery-released fish. Our findings are consistent with other minnows in the reproductive guild, where spawning may occur during low flows, but subsequent recruitment is poor or absent (Durham and Wilde 2006, 2009; Perkin et al. 2019). These results highlight the need for a greater understanding of the availability of habitats that promote survival and recruitment of eggs and larvae to adults at differing flows.

We observed variable reproductive investment among and within years. In high flow years, GSI increased in March, peaked in mid to late April, and quickly declined through June. However, during extreme drought, GSI levels appeared to be elevated in a few females through July with a peak in mid-May. While additional information could elucidate this pattern, this extended duration of elevated GSI could be the result of a lack of an elevated streamflow serving as a spawning cue. As no appreciable change in flow occurred from April through July 2018, it is likely flow conditions were not suitable for spawning and fish did not release ova for as long as possible. In contrast, we did not observe any females with elevated GSI in July or August in high flow years, providing little evidence spawning occurred during monsoons. In another pelagic broadcast-spawning minnow, smalleye shiner (Notropis buccula), low-level, asynchronous spawning occurs throughout spring and summer, whereas synchronized, intense spawning occurs when streamflow is elevated (Durham and Wilde 2008). A lack of synchronized, intense spawning during extreme drought could be one possible explanation for the elevated GSI we observed through early July of 2018.

Based on laboratory observations (Platania and Altenbach 1998) and preliminary histological examination (U.S Fish and Wildlife Service, unpubl. data), RGS minnow are likely a batch spawning species (sensu Brown-Peterson et al. 2011). Batch-spawning species have multiple cohorts of oocytes that are recruited into vitellogenesis throughout the spawning season (BrownPeterson et al. 2011). Many batch-spawning minnows appear to have extended spawning seasons (e.g., months, Heins and Rabito 1986; Durham and Wilde 2008; Archdeacon et al. 2015). Histological examination of oocyte recruitment into vitellogenesis would be required to confirm spawning condition of the few females that exhibited elevated GSI after July, but it is unlikely that many were capable of spawning. Spawning during short increases in streamflow following monsoon rain events (June through September) appears unlikely given the overall rarity and low GSI of adult female RGS minnow. Our observations are 

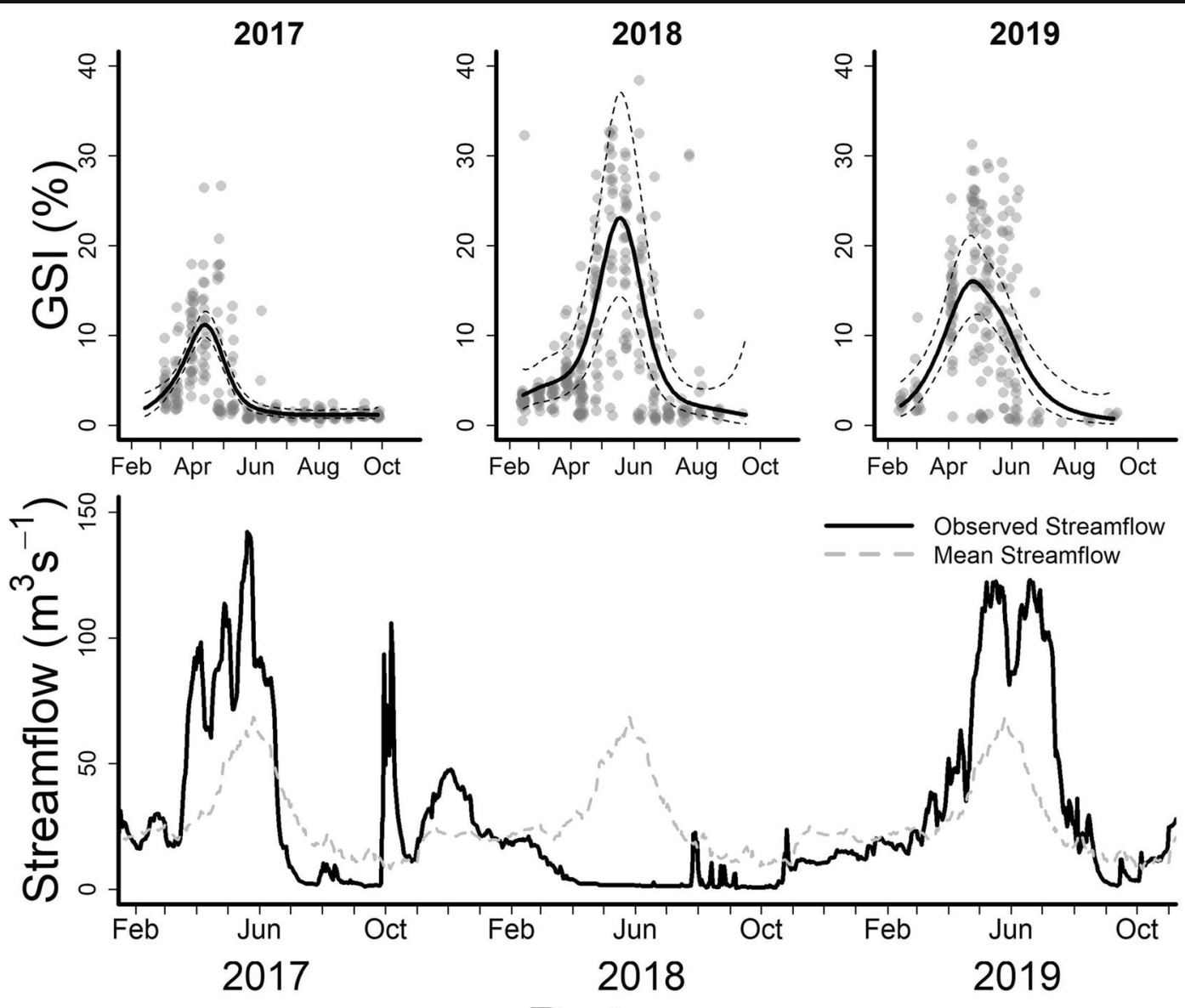

Fig. 2 Gonadosomatic Index (GSI) of female Rio Grande silvery minnow collected (top) and respective flow regime (bottom) in the San Acacia reach of the Middle Rio Grande, New Mexico. Points are individual female GSI scores, and sample medians (thick lines)

consistent with other studies of reproductive phenology of RGS minnow. For example, larval RGS minnow typically appear in collections in mid-May (Turner et al. 2010), though the date of first appearance appears to be shifting earlier in the year (Krabbenhoft et al. 2014). Spawning readiness is driven by water temperature in other freshwater fishes (Fraser et al. 2019). However, peak population-level GSI, and presumably spawning capability, may not overlap with peak streamflow runoff, as observed during extreme drought. Similarly, conditions for peak larval production may or may not coincide with peak spawning readiness. Thus, further research is required to determine if peak population spawning overlaps with the availability of habitat for larval fishes. and $95 \%$ confidence interval (dashed lines) were estimated from generalized additive models and depict significant changes in GSI over time in all three years

Use of temporally overlapping standardized population monitoring and reproductive investment data allowed us to make more informative inferences than either dataset taken independently. Examination of just GSI could lead to the conclusion that RGS minnow reproduce annually and drought has no effect on the species. Similarly, examination of just recruitment data would indicate that the fish do not reproduce during years with low spring flows. Pairing the both sets of data allows conservation managers to narrow down the life-stages where recruitment failure is occurring. Our results show that for RGS minnow spawning occurs annually regardless of flows, and recruitment failure occurs post-spawn. Juvenile RGS minnow rarely show up in isolated pools that form in June and July during low-flow years (Archdeacon 2016), which further 
Fig. 3 Temporal change in age composition (top) and sitespecific catch-per-unit-effort (bottom) of Rio Grande silvery minnow in the San Acacia reach of the Middle Rio Grande, New Mexico. Black line depicts mean catch-per-unit-effort for each period
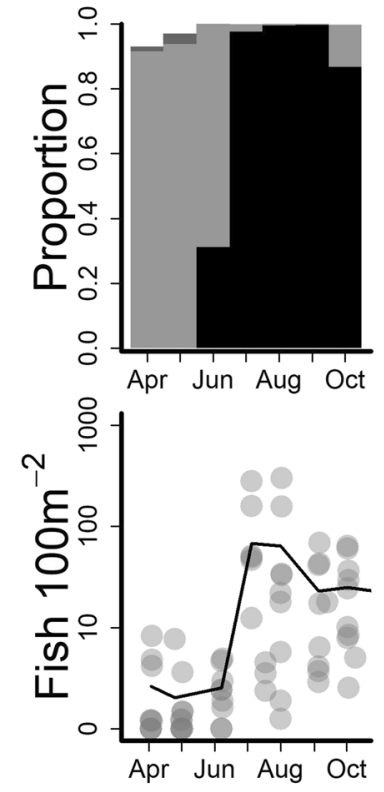

2017
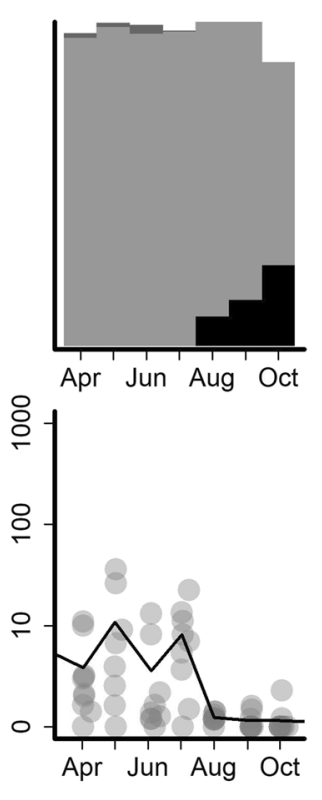

2018 Date
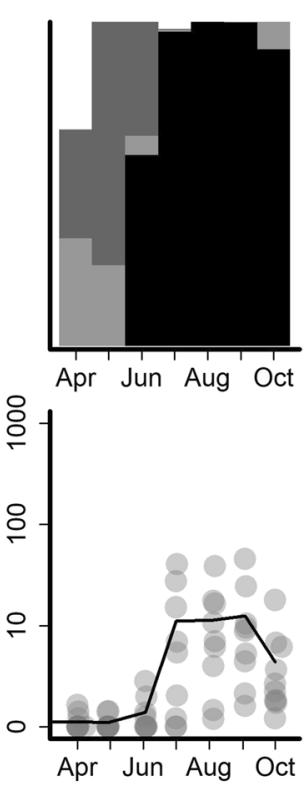

2019 suggests the critical time period during which recruitment failure occurs must be April and May. Thus, we predict recruitment failure is likely linked to access and availability of habitat that retains eggs and larvae (Dudley and Platania 2007) and post-spawn nursery habitats (Pease et al. 2006; Valdez et al. 2019).

Four other species of pelagic broadcast-spawning minnows, speckled chub, (Macrhybopsis aestivalis), Rio Grande shiner ( $N$. jemzanus), Phantom shiner (N. orca), and Rio Grande bluntnose shiner (N. simus simus) were extirpated from the Rio Grande in New Mexico by the 1970s (Bestgen and Platania 1990). The only remaining members of this reproductive guild in the Rio Grande of New Mexico are the RGS minnow and flathead chub (Platygobio gracilis), which spawns denser, demersal eggs (Bestgen et al. 2016). These extirpations are likely the result of water management and flood control infrastructure that have changed the natural flow regime. These changes have reduced lateral channel connectivity, which have in turn reduced the number of low-velocity nursery habitats that were historically available during spring flows. Increased rate of downstream transport of eggs and larvae, coupled with barriers to upstream dispersal and channel drying, have negatively affected many pelagic broadcast-spawning species of the western United States (Dudley and Platania 2007; Perkin et al. 2015). While restoration of floodplain habitat can be beneficial for RGS minnow (Pease et al. 2006; Gonzales et al. 2014; Valdez et al. 2019), these critical habitats will only have a positive effect on recruitment when streamflow is great enough to inundate them, and occur when the RGS minnow are capable of spawning to have a positive effect on recruitment. Efforts to recover RGS minnow are hampered by the unpredictable nature of drought, and few management actions are available to mitigate the negative effects of low flows. Consequently, this can lead to low recruitment in a single cohort, as we observed in 2018. For a short-lived species, sequential years of drought, such as what occurred from 2012 to 2014, can quickly lead to population collapse (Archdeacon 2016).

Recovery and persistence of a species following disturbance hinges on resilience and resistance of the species to the disturbance (Lake 2013). Resilience is the ability of a species to recover from a disturbance to levels similar to pre-disturbance, whereas resistance is 
the ability of the species to remain unchanged by the disturbance (Lake 2000; McCluney et al. 2014). In our study, RGS minnow were resilient but not resistant to drought. Following the extreme drought in 2018, recruitment of eggs to juveniles was nearly absent and overall catch rates declined sharply. However, RGS minnow was able to successfully recruit in 2019 and overall numbers increased but remained at only $20 \%$ of 2017 pre-disturbance levels. Resilience of RGS minnow following extreme drought is bolstered by high fecundity relative to small body size (Caldwell et al. 2019) and high capacity for dispersal (Archdeacon and Remshardt 2012; Archdeacon et al. 2018; Platania et al. 2020), allowing them to quickly repopulate areas. Furthermore, using genetically representative fish, hatchery augmentation is designed to supplement wild populations in years with poor recruitment. Following multiple years of drought, up to $90 \%$ of RGS minnow rescued from isolated pools in summer are hatchery fish (Archdeacon 2016), and, based on population monitoring data, likely contributed to spawning biomass. Although hatchery fish have not prevented population crashes, augmentation has likely prevented further loss of genetic diversity in RGS minnow (Osborne et al. 2012), though full evaluation of the effects of augmentation are likely confounded by barriers to dispersal (Carson et al. 2020).

Our work highlights the need for changes in water management that balances human demands with the needs of wildlife. Rio Grande silvery minnow showed a remarkable resilience to extreme drought, providing hope that a balance between water use and conservation can lead to a stable population of RGS minnow in the Rio Grande. Several species of pelagic broadcastspawning minnows of the western United States are declining or have already been extirpated (Worthington et al. 2018). Shorter-lived species in fragmented habitats may lack the resilience to persist through even a single drought (Pennock et al. 2017). Most of these species do not have large-scale breeding programs to augment wild populations after failed recruitment. If extreme droughts, natural or anthropogenic, become more common, more of these minnows may require hatchery augmentation for persistence or face extirpation. Continued conservation management and research aimed at restoring natural flow regimes, improving both lateral and longitudinal connectivity, and creating nursery habitat for critical life stages can help improve persistence RGS minnow and other pelagic broadcast-spawning minnows (Dudley and Platania 2007; Hoagstrom and Turner 2015; Valdez et al. 2019). Despite their resilience, RGS minnow remain in a precarious position. Reaching recovery goals will be difficult without management actions designed to prevent consecutive years of recruitment failure, which is essential for the persistence of short-lived species.

Acknowledgements Funding was provided by the U.S. Bureau of Reclamation, Interagency Agreement 02-AA-40-8190. We thank Steve Platania and Rob Dudley of American Southwest Ichthyological Researchers LLC, for Rio Grande silvery minnow monitoring data. We thank Scott Mullner and Lyle Thomas for assistance with fish collections and dissections, Kacie Coffey, Monika Hobbs, and Craig Ford for additional assistance with fish collections. We thank Jane Rogosch, Nate Caswell, and three anonymous reviewers for constructive comments on the manuscript. The views presented here are the authors' and do not necessarily represent the views of the U. S. Fish and Wildlife Service. Any use of trade, firm, or product names is for descriptive purposes only and does not imply endorsement by the U. S. Government. The authors have no conflicts of interest. The data that support the findings of this study are available from the corresponding author upon reasonable request.

Author contributions All authors contributed to the study conception, design, laboratory work, and the manuscript. Field work was performed by Thomas P. Archdeacon and Joshua D. Grant. Statistical analyses and preparation of figures was done by Thomas P. Archdeacon.

Funding information Funding was provided by the U.S. Bureau of Reclamation, Interagency Agreement 02-AA-40-8190.Data AvailabilityThe datasets generated during and/or analyzed during the current study are available from the corresponding author on reasonable request.

\section{Compliance with Ethical Standards}

Conflict of interest The authors declare they have no conflicting or competing interests.

Ethics approval Field collection, euthanasia, and preservation of fish followed the American Fisheries Society "Guidelines for the Use of Fishes in Research". Fish were collected under U.S. Fish and Wildlife Service permit TE-676811-5 and New Mexico Department of Game and Fish permit 1776. This article does not contain any studies with human participants.

Consent to publish Not applicable.

Code availability Program $\mathrm{R}$ is freely available. No custom code was used. 
Open Access This article is licensed under a Creative Commons Attribution 4.0 International License, which permits use, sharing, adaptation, distribution and reproduction in any medium or format, as long as you give appropriate credit to the original author(s) and the source, provide a link to the Creative Commons licence, and indicate if changes were made. The images or other third party material in this article are included in the article's Creative Commons licence, unless indicated otherwise in a credit line to the material. If material is not included in the article's Creative Commons licence and your intended use is not permitted by statutory regulation or exceeds the permitted use, you will need to obtain permission directly from the copyright holder. To view a copy of this licence, visit http://creativecommons.org/licenses/by/4.0/.

\section{References}

Achdeacon TP, Davenport SR, Grant JD, Henry EB (2018) Mass upstream dispersal of pelagic-broadcast spawning cyprinids in the Rio Grande and Pecos River, New Mexico. West North Am Nat 78:100-105. https://doi.org/10.3398/064.078.0110

Archdeacon TP (2016) Reduction in spring flows threatens Rio Grande silvery minnow: trends in abundance during river intermittency. Trans Am Fish Soc 145:754-765. https://oi. org/10.1080/00028487.2016.1159611

Archdeacon TP, Remshardt WJ (2012) Observations of hatcheryreared Rio Grande silvery minnow using a fishway. North Am J Fish Manag 32(4):648-655. https://doi.org/10.1080 $/ 02755947.2012 .681013$

Archdeacon TP, Blocker SD, Davenport SR, Henderson KJ (2015) Seasonal variation in reproductive condition of the Pecos bluntnose shiner (Notropis simus pecosensis). West North Am Nat 75:271-280. https://doi.org/10.3398 /064.075.0304

Archdeacon TP, Reale JK, Gonzales EJ, Grant JD (2020) Effects of seining effort and site length on variability of small-bodied fishcatch-rates in a sand-bed river. River Res Appl. https://doi.org/10.1002/RRA.3666

Balon EK (1975) Reproductive guilds of fishes: a proposal and definition. J Fish Res Board Can 32:821-864. https://doi. org/10.1139/f75-110

Balon EK (1981) Additions and amendments to the classification of reproductive style in fishes. Environ Biol Fish 6:377-389. https://doi.org/10.1007/BF00005769

Bernardo JM, Ilhéu M, Matono P, Costa AM (2003) Interannual variation of fish assemblage structure in a Mediterranean river: implications of streamflow on the dominance of native or exotic species. River Res Appl 19:521-532. https://doi. org/10.1002/rra. 726

Bestgen KR, Platania SP (1990) Extirpation of Notropis simus simus (Cope) and Notropis orca Woolman (Pisces: Cyprinidae) from the Rio Grande in New Mexico, with notes on their life history. Occas Pap Mus Southwest Biol 6:1-8

Bestgen KR, Platania SP (1991) Status and conservation of the Rio Grande silvery minnow, Hybognathus amarus. Southwest Nat 36: 225-232. https://doi.org/10.2307/3671925

Bestgen KR, Crockett HJ, Haworth MR, Fitzpatrick RM (2016) Production of nonadhesive eggs by flathead chub and implications for downstream transport and conservation. J Fish Wildlife Manag 7:434-443

Blythe TL, Schmidt JC (2018) Estimating the natural flow regime of rivers with long-standing development: the northern branch of the Rio Grande. Water Resour Res 54:12121236. https://doi.org/10.1002/2017WR021919

Brewer SK, Rabeni CF, Papoulias DM (2008) Comparing histology and gonadosomatic index for determining spawning condition of small-bodied riverine fishes. Ecol Freshw Fish 17:54-58. https://doi.org/10.1111/j.1600-0633.2007.00256. $\mathrm{X}$

Brown-Peterson NJ, Wyanski DM, Saborido-Rey F, Macewicz BJ, Lowerre-Barbieri SK (2011) A standardized terminology for describing reproductive development in fishes. Mar Coast Fish: Dyn Manag Ecosyst Sci 3:52-70. https://doi. org/10.1080/19425120.2011.555724

Caldwell CA, Falco H, Knight W, Ulibarri M, Gould WR (2019) Reproductive potential of captive Rio Grande silvery minnow. North Am J Aquac 81:47-54. https://doi.org/10.1002 /naaq. 10068

Carson EW, Osborne MJ, Turner TF (2020) Relationship of effective size to hatchery supplementation and habitat connectivity in a simulated population of Rio Grande Silvery Minnow. North Am J Fish Manage. Accepted Author Manuscript. https://doi.org/10.1002/nafm.10453

Dudley RK, Platania SP (2007) Flow regulation and fragmentation imperil pelagic-spawning riverine fishes. Ecol Appl 17: 2074-2086. https://doi.org/10.1890/06-1252.1

Dudley RK, Barkalow AL, Robbins TO, Platania SP, White GC (2019) Rio Grande silvery minnow reproductive monitoring during 2019. Submitted to the U. S. Bureau of Reclamation, Albuquerque, New Mexico, USA. https://webapps.usgs. gov/MRGESCP/documents/default.html Accessed 27 May 2020

Dudley RK, Platania SP, White GC (2020) Rio Grande silvery minnow population monitoring during 2019 . Submitted to the U. S. Bureau of Reclamation, Albuquerque, New Mexico, USA. https://webapps. usgs.gov/MRGESCP/documents/default.html Accessed 24 Feb 2020

Durham BW, Wilde GR (2006) Influence of Stream Discharge on Reproductive Success of a Prairie Stream Fish Assemblage. Trans Am Fish Soc 135:1644-1653. https://doi.org/10.1577 /T05-133.1

Durham BW, Wilde GR (2008) Asynchronous and synchronous spawning by the smalleye shiner Notropis buccula from the Brazos River, Texas. Ecol Freshw Fish 17:528-541. https://doi.org/10.1111/j.1600-0633.2008.00303.x

Durham BW, Wilde GR (2009) Effects of streamflow intermittency on the reproductive success of two broadcast-spawning cyprinids. Copeia 2009:21-28. https://doi.org/10.1643/CE07-166

Edwards RE (2017) Biological monitoring of the reintroduction efforts of the Rio Grande silvery minnow into the Big Bend region of Texas and Mexico. Submitted to Texas Parks \& Wildlife. https://tpwd.texas. gov/business/grants/wildlife/section-6/docs/fish/tx-e169-r-final-performance-report.pdf. Accessed 10 Feb 2020

Fraser GS, Bestgen KR, Winkelman DL, Thompson KG (2019) Temperature - not flow-predicts native fish reproduction 
with implications for climate change. Trans Am Fish Soc 148:509-527. https://doi.org/10.1002/tafs.10151

Gido KB, Propst DL (2012) Long-term dynamics of native and nonnative fishes in the San Juan River, New Mexico and Utah, under partially managed flow regime. Trans Am Fish Soc 141: 645-659. https://doi.org/10.1080/00028487.2012.683471

Glieck PH (2003) Global freshwater resources: soft-path solutions for the 21st century. Sci 302:1524-1528. https://doi. org/10.1126/science. 1089967

Gonzales EJ, Tave D, Haggerty GM (2014) Endangered Rio Grande silvery minnow use constructed floodplain habitat. Ecohydrol 7:1087-1093. https://doi.org/10.1002/eco.1438

Gundmonsson L, Leonard M, Do HX, Westra S, Seneviratne SI (2019) Observed trends in global indicators of mean and extreme streamflow. Geophys Res Lett 46:756-766. https://doi.org/10.1029/2018GL079725

Heins DC, Rabito FG (1986) Spawning performance in North American minnows: direct evidence of the occurrence of multiple clutches in the genus Notropis. J Fish Biol 28: 343-357. https://doi.org/10.1111/j.1095-8649.1986. tb05171.x

Hoagstrom CW, Turner TF (2015) Recruitment ecology of pelagic-broadcast spawning minnows: paradigms from the ocean advance science and conservation of imperiled freshwater fauna. Fish Fish 16:282-299. https://doi.org/10.1111 /faf. 12054

Horwitz RJ, Keller DH, Overbeck PF, Platania SP, Dudley RK, Carson EW (2018) Age and growth of the Rio Grande silvery minnow, an endangered, short-lived cyprinid of the North American Southwest. Trans Am Fish Soc 147:265-277. https://doi.org/10.1002/tafs.10012

Hutson AM, Toya LA, Tave D (2018) Determining preferred spawning habitat of the endangered Rio Grande silvery minnow by hydrological manipulation of a conservation aquaculture facility and the implications for management. Ecohydrol 11:e1964. https://doi.org/10.1002/eco.1964

Kominoski JS, Ruhí A, Hagler MM, Petersen K, Sabo JL, Sinha T, Sankarasubramanian A, Olden JD (2018) Patterns and drivers of fish extirpations in rivers of the American Southwest and Southeast. Glob Chang Biol 24:1175-1185. https://doi.org/10.1111/gcb.13940

Krabbenhoft TJ, Platania SP, Turner TF (2014) Interannual variation in reproductive phenology in a riverine fish assemblage: implications for predicting the effects of climate change and altered flow regimes. Freshw Biol 59:1744-1754. https://doi. org/10.1111/fwb. 12379

Lake PS (2000) Disturbance, patchiness, and diversity in streams. J North Am Benthol Soc 19:573-592. https://doi. org/10.2307/1468118

Lake PS (2013) Resistance, resilience and restoration. Ecol Manag Restor 14:20-24. https://doi.org/10.1111/emr.12016

Massong T, Tashjian P, Makar P (2006) Recent Channel Incision and Floodplain Evolution within the Middle Rio Grande, NM. Proc 8th Fed Interag Sediment Conferen Reno, Nevada, USA

McCluney KE, Poff NL, Palmer MA, Thorp JH, Poole GC, Williams BS, Williams MR, Baron JS (2014) Riverine macrosystems ecology: sensitivity, resistance, and resilience of whole river basins with human alterations. Front Ecol the Environ 12:48-58. https://doi.org/10.1890/120367
McManamay R, Frimpong EA (2015) Hydrologic filtering of fish life history strategies across the United States: implications for stream flow alteration. Ecol Appl 25:243-263. https://doi. org/10.1890/14-0247.1

Mims MC, Olden JD (2012) Life history theory predicts fish assemblage response to hydrologic regimes. Ecol 93:34-45. https://doi.org/10.1890/11-0370.1

Osborne MJ, Carson EW, Turner TF (2012) Genetic monitoring and complex population dynamics: insights from a 12-year study of the Rio Grande silvery minnow. Evol Appl 5:553574. https://doi.org/10.1111/j.1752-4571.2011.00235.x

Osborne MJ, Perez TL, Altenbach CS, Turner TF (2013) Genetic analysis of captive spawning strategies for the endangered Rio Grande silvery minnow. J Hered 104:437-446. https://doi.org/10.1093/jhered/est013

Overpeck JT, Udall B (2020) Climate change and the aridification of North America. Proc Natl Acad Sci USA:202006323. https://doi.org/10.1073/pnas.2006323117

Pease AA, Davis JJ, Edwards MS, Turner TF (2006) Habitat and resource use by larval and juvenile fishes in an arid-land river (Rio Grande, New Mexico). Freshw Biol 51:475-486. https://doi.org/10.1111/j.1365-2427.2005.01506.x

Pennock CA, Gido KB, Perkin JS, Weaver VD, Davenport SR, Caldwell JM (2017) Collapsing range of an endemic Great Plains minnow, peppered chub Macrhybopsis tetranema. Am Midl Nat 177:57-68

Perkin JS, Gido KB, Costigan KH, Daniels MD, Johnson ER (2015) Fragmentation and drying ratchet down Great Plains stream fish diversity. Aquat Conserv: Mar Freshw Ecosyst 25:639-655. https://doi.org/10.1002/aqc.2501

Perkin JS, Starks TA, Pennock CA, Gido KB, Hopper GW, Hedden SC (2019) Extreme drought causes fish recruitment failure in a fragmented Great Plains riverscape. Ecohydrol 12. https://doi.org/10.1002/eco. 2120

Platania SP, Altenbach CS (1998) Reproductive strategies and egg types of seven Rio Grande Basin cyprinids. Copeia 1998: 559-569. https://doi.org/10.2307/1447786

Platania SP, Mortensen JG, Farrington MA, Brandenburg WH, Dudley RK (2020) Dispersal of stocked Rio Grande silvery minnow (Hybognathus amarus) in the middle Rio Grande, New Mexico. Southwest Nat 64:31-42. https://doi. org/10.1894/0038-4909-64-1-31

R Core Team (2018) $R$ : A language and environment for statistical computing. R Foundation for Statistical Computing. Vienna, Austria. http://www.R-project.org

Rideout RM, Tomkiewicz J (2011) Skipped spawning in fishes: more common than you might think. Mar Coast Fish 3:176189. https://doi.org/10.1080/19425120.2011.556943

Rideout RM, Rose GA, Burton MPM (2005) Skipped spawning in female iteroparous fishes. Fish Fish 6:50-72. https://doi. org/10.1111/j.1467-2679.2005.00174.x

Ruhí A, Holmes E, Rinne JN, Sabo JL (2015) Anomalous droughts, not invasion, decrease persistence of native fishes in a desert river. Glob Chang Biol 21:1482-1496. https://doi. org/10.1111/gcb. 12780

Ruhí A, Olden JD, Sabo JL (2016) Declining streamflow induces collapse and replacement of native fish in the American Southwest. Front Ecol Environ 14:465-472. https://doi. org/10.1002/fee. 1424

Seager R, Ting M, Held I, Kushnir Y, Lu J, Vecchi G, Huan H, Harnik N, Leetmaa A, Lau N, Li C, Velez J, Naik N (2007) 
Model projections of an imminent transition to a more arid climate in southwestern North America. Science 316:11811184. https://doi.org/10.1126/science.1139601

Seegrist DW, Gard R (1972) Effects of floods on trout in Sagehen Creek, California. Trans Am Fish Soc 101:487-482. https://doi.org/10.1577/1548-8659(1972)101<478 :EOFOTI $>2.0 . \mathrm{CO} ; 2$

Sheppard PR, Comrie AC, Packin GD, Angersbach K, Hughes MK (2002) Climate of the US Southwest. Clim Res 21:219238. https://doi.org/10.3354/cr021219

Stewart IT, Cayan DR, Dettinger MD (2004) Changes in snowmelt runoff timing in western North America under a 'business as usual' climate change scenario. Clim Chang 62:217232. https://doi.org/10.1023/B:CLIM.0000013702.22656.e8

Swanson BJ, Meyer GA, Coonrad JE (2011) Historical channel narrowing along the Rio Grande near Albuquerque, New Mexico in response to peak discharge reductions and engineering: magnitude and uncertainty of change from air photo measurements. Earth Surf Proc Landf 36:885-900. https://doi.org/10.1002/esp.2119

Treviño-Robinson D (1959) The ichthyofauna of the Lower Rio Grande, Texas and Mexico. Copeia 1959, 253-256. https://doi.org/10.2307/1440404

Turner TF, Krabbenhoft TJ, Burdett AS (2010) Reproductive phenology and fish community structure in an arid-land river system. Am Fish Soc Symp 73:427-446

Valdez RA, Haggerty GM, Richard K, Klobucar D (2019) Managed spring runoff to improve nursery floodplain habitat for endangered Rio Grande silvery minnow. Ecohydrol 12. https://doi.org/10.1002/eco.2134

Widmer AM, Fluder JJ III, Kehmeier JW, Medley CN, Valdez RA (2010) Drift and retention of pelagic spawning minnow eggs in a regulated river. River Res Appl 28:193-203. https://doi. org/10.1002/rra.1454

Wood SN (2011) Fast stable restricted maximum likelihood and marginal likelihood estimation of semiparametric generalized linear models. J R Stat Soc 73:3-36. https://doi.org/10.1111 /j.1467-9868.2010.00749.x

Wootton RJ (1998) Ecology of teleost fishes, second edition. Kluwer Academic Publishers, Dordrecht, The Netherlands

Worthington TA, Echelle AA, Perkin JS, Mollenhauer R, Farless N, Dyer JJ, Logue D, Brewer SK (2018) The emblematic minnows of the North American Great Plains: a synthesis of threats and conservations opportunities. Fish Fish 19:271307. https://doi.org/10.1111/faf.12254

Yan H, Sun N, Wigmosta M, Skaggs R, Leung LR, Coleman A, Hou Z (2019) Observed spatiotemporal changes in the mechanisms of extreme water available for runoff in the western United States. Geophys Res Lett 46:767-775. https://doi. org/10.1029/2018GL080260

Publisher's note Springer Nature remains neutral with regard to jurisdictional claims in published maps and institutional affiliations. 